\title{
A NORMA DO AMOR: RELACIONAMENTO E ORDEM SOCIAL EM MACHADO DE ASSIS
}

\author{
Nathalia Pinto \\ Submetido em 15 de abril de 2019. \\ Aceito para publicação em 04 de setembro de 2019. \\ Cadernos do IL, Porto Alegre, n. ${ }^{\circ}$ 58, outubro. p. 121-133.
}

\section{POLÍTICA DE DIREITO AUTORAL}

Autores que publicam nesta revista concordam com os seguintes termos:

(a) Os autores mantêm os direitos autorais e concedem à revista o direito de primeira publicação, com o trabalho simultaneamente licenciado sob a Creative Commons Attribution License, permitindo o compartilhamento do trabalho com reconhecimento da autoria do trabalho e publicação inicial nesta revista.

(b) Os autores têm autorização para assumir contratos adicionais separadamente, para distribuição não exclusiva da versão do trabalho publicada nesta revista (ex.: publicar em repositório institucional ou como capítulo de livro), com reconhecimento de autoria e publicação inicial nesta revista.

(c) Os autores têm permissão e são estimulados a publicar e distribuir seu trabalho online (ex.: em repositórios institucionais ou na sua página pessoal) a qualquer ponto antes ou durante o processo editorial, já que isso pode gerar alterações produtivas, bem como aumentar o impacto e a citação do trabalho publicado.

(d) Os autores estão conscientes de que a revista não se responsabiliza pela solicitação ou pelo pagamento de direitos autorais referentes às imagens incorporadas ao artigo. A obtenção de autorização para a publicação de imagens, de autoria do próprio autor do artigo ou de terceiros, é de responsabilidade do autor. Por esta razão, para todos os artigos que contenham imagens, o autor deve ter uma autorização do uso da imagem, sem qualquer ônus financeiro para os Cadernos do IL.

\section{POLÍTICA DE ACESSO LIVRE}

Esta revista oferece acesso livre imediato ao seu conteúdo, seguindo o princípio de que disponibilizar gratuitamente o conhecimento científico ao público proporciona sua democratização.

http://seer.ufrgs.br/cadernosdoil/index

Segunda-feira, 07 de outubro de 2019. 


\title{
A NORMA DO AMOR: RELACIONAMENTO E ORDEM SOCIAL EM MACHADO DE ASSIS
}

\section{THE NORM OF LOVE: RELATIONSHIP AND SOCIAL ORDER IN MACHADO DE ASSIS}

\begin{abstract}
Nathalia Pinto $^{1}$
RESUMO: Vários críticos que estudaram a prosa machadiana mostraram que sua obra denuncia, comenta e ironiza a sociedade brasileira do século XIX em seus diferentes aspectos. Nada lhe escapou: desde a vida privada até a pública, figuram em seus romances e contos os vícios velados da burguesia brasileira que se queria europeizada. No presente artigo, pretendemos, na esteira do trabalho destes críticos, mostrar como as relações amorosas, entendidas também como relações sociais, são trabalhadas em três contos do autor que têm relações amorosas ou sentimentais em seu centro e que são atravessadas pelo dado social: neles está o retrato tanto do casal burguês quanto do casal pobre, menos comprometido com o código burguês, e o valor social do matrimônio.
\end{abstract}

PALAVRAS-CHAVE: Machado de Assis; conto; relações amorosas; ordem social.

ABSTRACT: Several critics who have studied Machado's prose have shown that his work denounces, comments on, and makes fun of nineteenth-century Brazilian society in its different aspects. Nothing escaped him: from private to public life, his novels and short stories feature the veiled vices of the Brazilian bourgeoisie that wanted to be Europeanized. In the present article, we intend, in the wake of the work of these critics, to show how love relations, also understood as social relations, are worked in three short stories of the author that have love or sentimental relations in their center and which are crossed by the social data: in them there is the portrait of both the bourgeois couple and the poor couple, less committed to the bourgeois code, and the social value of marriage.

KEYWORDS: Machado de Assis; short story; love relationship; social order.

O nosso amor é mais gostoso

Nossa saudade dura mais O nosso abraço mais apertado

Nóis não usa as bleque tais

Minhas juras são mais juras

Meus carinho mais carinhoso

(Adoniran Barbosa/ Gianfrancesco Guarnieri)

\section{Introdução}

Machado de Assis superou como poucos escritores brasileiros de sua época os esquemas e idealizações românticos. Sua identificação com a prosa realista, aliada ao

\footnotetext{
${ }^{1}$ Mestra em Literatura Brasileira pela Universidade Federal do Rio Grande do Sul. Doutoranda em Estudos Literários Aplicados - Literatura, Ensino e Escrita Criativa pela Universidade Federal do Rio Grande do Sul. E-mail: nathalia@ colegioconcordia.com.br
} 
seu gênio sutil e a sua capacidade de leitura do mundo em que vivia e escrevia, permitiu que sua narrativa formasse provavelmente o desenho mais bem-acabado que a literatura registrou da vida brasileira do século XIX. Mesmo quando sua pena se volta para a vida privada, seus textos deixam ver o modo de ser e pensar do Brasil de sua época, tendo como poderoso subtexto o cruel antagonismo de classe de uma sociedade que evitava sua identidade colonial, mas não se livrava das amarras da lógica e economia escravocratas.

Um perfeito exemplo dessa dimensão ideológica que se esconde por trás de episódios que, à primeira vista, parecem restritos à trivialidade da vida cotidiana das personagens, está no texto de Roberto Schwarz "O sentido histórico da crueldade em Machado de Assis". Nele o autor retoma o breve romance de Brás e Eugênia, de Memórias póstumas de Brás Cubas (1881), e mostra que a razão fundamental para o não comprometimento de Brás com a jovem passa longe da deficiência física da moça, exageradamente sublinhada pelo narrador que a define sempre nos termos desta característica: Eugênia é coxa, ainda que bonita. O que há entre Brás e Eugênia é principalmente uma diferença de classe e de linhagem. O rapaz é "um Cubas!", como exclama seu pai, para convencê-lo a investir em uma carreira que lhe dê celebridade, já Eugênia é uma filha bastarda. É mais fácil, mesmo para um cínico como Brás, acusar a inferioridade física de Eugênia (cuja responsabilidade cai na conta da natureza) do que sua inferioridade socioeconômica.

Para Brás, assim como para muitas das personagens machadianas, exemplares das elites brasileiras da época, o relacionamento amoroso e, consequentemente, o casamento são encarados como arranjos não só sociais como econômicos. Muito mais do que a realização de um apelo sentimental, esses laços têm uma função utilitária. Na trajetória de Brás Cubas, todas as suas tentativas de contrair matrimônio escondem a busca pela respeitabilidade que a figura de pai de família numa sociedade patriarcal evoca, imagem esta fundamental para a decolagem de sua tão almejada carreira política.

Outro ponto apontado por Schwarz sobre o episódio é a força moral e a dignidade do caráter de Eugênia. A jovem se mostra consciente dos ditames sociais que impedem essa relação e não assume voluntariamente a inferioridade na qual a situação a coloca. Esse orgulho dos pobres, especialmente das mulheres, que dessa forma são duplamente oprimidas pelo senhor-homem, também é recorrente em muitas personagens machadianas, inclusive na dinâmica das relações amorosas.

A análise de Schwarz dessa dupla opressão é bastante exemplar do quanto, na narrativa de Machado de Assis, as relações amorosas e/ou conjugais são atravessadas pelo dado da ordem social brasileira do século XIX. As obras reconhecidas como resultado da maturidade do escritor transcendem completamente a falácia do amor romântico e mostram homens e mulheres presos, por obrigação ou por vontade, às relações que, antes de mais nada, se constituem principalmente na esfera social. De acordo com o autor, "o episódio de Eugênia é uma obra-prima da técnica realista" (SCHWARZ, 2014, p. 79).

Casos como o da relação analisada por Schwarz aparecem em toda a ficção machadiana, tanto nos romances como nos contos. As personagens e os laços que as unem são reveladores, como no caso mencionado, não só de violentos antagonismos de classe, como dos papéis estabelecidos para cada gênero dentro da dinâmica dessas relações, dos diferentes níveis de comprometimento e do valor desses laços dentro de cada classe social, assim como da dimensão social do casamento. Dessa forma, encontramos aí um exemplo da "solidariedade entre observação social, esquema 
dramático, organização das personagens e padrão - bem como ponto de vista de classe da prosa" (SCHWARZ, 2014, p. 67).

O presente artigo pretende analisar três contos de Machado de Assis publicados originalmente na Gazeta de Notícias, entre os anos de 1883 e 1884: "Capítulo dos chapéus", "O diplomático" e "Noite de almirante". O objetivo dessa análise é concentrar a reflexão na dimensão ideológica que se esconde por trás das relações afetivas que estão no centro dessas narrativas curtas. $\mathrm{O}$ fato de terem sido originalmente veiculadas a partir desse periódico é bastante significativo, uma vez que essa publicação, fundada em 1874 (ainda que Machado só comece a publicar em suas páginas a partir de 1881), foi "uma novidade entre os jornais brasileiros, pois era vendida nas ruas e não apenas para assinantes. Era um jornal liberal no melhor sentido da palavra, politicamente independente, vivo e empenhado em apoiar boas produções literárias" (GLEDSON, 2006, p. 38). É importante ainda, para a reflexão que queremos propor, considerar que a Gazeta de Notícias abriu grande espaço para a campanha abolicionista através da publicação de textos de José do Patrocínio, posicionando-se ainda como antimonarquista em pleno calor da hora dos debates em torno da República e da Abolição.

Essas informações são relevantes, pois caracterizam esse jornal como uma publicação de caráter progressista e inovador dentro do contexto de seu surgimento, comprometida com a grande literatura e os verdadeiros ideais liberais que, como mostrado por Schwarz em seu famoso "As ideias fora de lugar", estavam na boca e na pena das elites brasileiras da época, mas não nas ações. Ao publicar contos da natureza dos que serão analisados nesse artigo através desse veículo de comunicação, Machado de Assis oferece aos seus leitores uma radiografia das relações amorosas, familiares e sociais da burguesia brasileira oitocentista e, assim, lhes obriga a encarar as idiossincrasias e contradições implicadas em suas posições ideológicas, sua vida pública e privada.

\section{2 "Capítulo dos chapéus" e a quase rebelião de Eva}

Em "Capítulo dos chapéus", os leitores têm a oportunidade de encontrar o que John Gledson define como o "feminismo" (2006, p. 38) de Machado de Assis. Isso porque o conto se desenvolve em torno da figura de Mariana, a jovem esposa de Conrado, que lhe pediu que trocasse de chapéu, pois o que usava não lhe ficava bem. Em resposta Mariana recebe do marido a humilhação em forma de teoria: por razões filosóficas, Conrado não trocaria o chapéu. A verdade é que o marido fazia uma manobra discursiva, que nada dizia, aproveitando-se da limitação intelectual da esposa (que só lia os mesmos livros: A moreninha, Ivanhoé e o Pirata e Mot de l'enigme) para demovê-la da questão e não realizar seu desejo. A simples vontade da jovem não seria realizada principalmente porque ela não costumava se impor e sua atitude desagradou ao marido, que considerou sua teima "imperiosa e áspera" (ASSIS, 2008, p. 313).

O fato é que Mariana "era, de ordinário, uma criatura passiva, meiga, de uma plasticidade de encomenda" (p. 313). A própria oposição quanto ao chapéu de Conrado não partira dela, e sim de seu pai, que mais cedo lhe fizera uma visita e convencera a filha de que aquele acessório não estava de acordo com a posição social do marido. $\mathrm{O}$ velho acreditava que o chapéu fosse insuficiente para distinguir o genro advogado dos demais na rua. Em outras palavras, o único movimento de imposição de Mariana não 
aconteceu em nome da sua vontade, e sim da de seu pai. Ela oscila, assim, entre o desejo do pai e o do marido. Sua opinião, na verdade, não entra em questão e o marido desconsidera totalmente o seu pedido por desconhecer que a ideia partiu, na realidade, de um homem, o sogro. Sidney Chalhoub, ao relembrar os posicionamentos a respeito do debate abolicionista, discussão contemporânea de Machado de Assis, mostra que a preocupação com os senhores estava no centro da questão, pois tendo em vista o papel que desempenhavam na sociedade, não poderiam ser derrotados por uma lei que colocasse seus inferiores como vencedores: "o senhor tinha poder sobre o escravo, assim como o marido tinha direito sobre a mulher, o pai sobre o filho. Essa prerrogativa senhorial, o potestas, garantido na lei, constituía a força moral do senhor sobre seus subordinados - escravos, mulher e filhos, mas também parentela e agregados" (2003, n.p.). É interessante perceber que a mulher é listada ao lado dos escravos na representação do poderio dos senhores, pois ambos são propriedades dele e devem servi-lo e obedecê-lo. Além disso, a posição de Mariana nesse momento é de dupla submissão: ela é mulher/esposa e filha.

Ao contrário do que Conrado esperava da mulher, ela percebeu a humilhação pela qual passou, ficou irritada e decidiu se vingar: "sentiu que era um sarcasmo e, dentro de si, chorava de vergonha" (ASSIS, 2008, p. 314). Então vai à casa da amiga Sofia e lhe conta o episódio que vivera em sua casa. É interessante nesse ponto opor as descrições que o narrador faz de Mariana e Sofia. A primeira já foi caracterizada acima, e se diferencia de Sofia que é "não só muito senhora de si, mas também dos outros" ( $p$. 315). Era muito bonita e tinha o poder de cativar homens e mulheres pelo físico e pela personalidade envolvente. Assim, Sofia convenceu a amiga sem dificuldades de que deveriam passear um pouco, enfim, sair. Sua intenção com o convite feito a Mariana era "restituir-lhe a posse de si mesma" (p. 319). Ou seja, a esposa de Conrado não era dona de si.

Em várias passagens o conto fala sobre a aversão de Mariana a sair em público. Vivia reclusa em sua casa, à espera do marido, garantindo que nada nem ninguém alterasse a ordem doméstica dos objetos e das pessoas, enquanto, no passado, quando solteira, a jovem teria sido uma "andarilha" (p. 313). Depois de casada, mereceu de Sofia a acusação de que "está ficando um bicho-do-mato" (p. 317). O costume de ficar em casa está, assim, claramente relacionado ao fato de que Mariana agora era uma mulher casada. Por isso, quando a jovem sentiu o desejo de se vingar do marido, achou que sair à rua seria o plano ideal. Jurandir Freire Costa, em sua pesquisa sobre a norma familiar burguesa brasileira no século XIX, aponta que "o sinal mais evidente da reticência com que a família abordava ou se deixava penetrar pelo meio social era o confinamento doméstico das mulheres" (1983, p. 101). E, mais adiante, esclarece:

\footnotetext{
A mulher tímida, reticente nas relações com o estranho, com o extra-familiar, resumia em sua conduta às determinações sociais que a aprisionavam na casa. O casamento de "razão" ou interesse; a inexistência do sentimento de amor entre os cônjuges; a inferioridade de "raça" ou "espécie" que lhe foi tributada; a dependência econômica para com o homem (pai, irmão, tio, tutor) e a rígida divisão do trabalho social compunham a moldura do confinamento da mulher (p. 102).
}

Vemos então que o hábito de Mariana de se restringir ao ambiente doméstico não é só seu, mas sim das mulheres casadas da época. Se Sofia não cumpria frequentemente essa determinação, era em função de sua personalidade forte, de sua vaidade e de seu caráter sedutor: era "Honesta, mas namoradeira" (ASSIS, 2008, p. 
315) e gostava de ser vista e admirada, de fazer parte da vida agitada da rua. Era casada, vivia em casa uma relação que considerava mais democrática do que a que havia entre Mariana e Conrado, pois conseguia ser ouvida, expor e impor seus desejos ao marido: "Olhe, eu cá vivo muito bem com meu Ricardo; temos muita harmonia. Não lhe peço uma coisa que não me faça logo; mesmo quando não tem vontade nenhuma, basta que eu feche a cara, obedece logo" (p. 315). Em seu diálogo com a amiga, falando sobre o matrimônio, Sofia usa as palavras "despotismo" (p. 315) e "tirania” (p. 316) para caracterizar essa relação. Ou seja, Sofia pode sair, pois não aceita passivamente o papel de esposa que a sociedade burguesa lhe impõe.

Há ainda outro dado sobre o qual vale a pena refletir. A narrativa não traz qualquer informação sobre como se deu o envolvimento de Mariana e Conrado. Não se sabe se, como apontado acima por Costa, tratava-se de um matrimônio arranjado, o que era muito comum entre as famílias burguesas da época. O pai de Mariana, aquele que, nesse caso, seria o responsável pelo arranjo e pela escolha de Conrado como marido da filha, aparece no conto apenas para se opor ao uso do chapéu do genro porque está preocupado com a figura que faria em público um advogado usando um chapéu baixo. Fica claro então que o sogro se orgulha da posição ocupada pelo genro e preza por ela a ponto de insuflar a filha a se opor ao marido em nome da sua distinção social. Conrado poderia, portanto, ter sido escolhido pelo pai de Mariana, ou ainda, no mínimo, a união não se deu contra a vontade do pai da moça, e sim com seu orgulhoso apoio. Dessa forma, não é arbitrário considerar a possibilidade de que o casamento de Mariana e Conrado tenha se dado através de um desses acordos de interesses, nos quais, ao menos inicialmente, o laço entre os cônjuges é mais um arranjo do que um sentimento.

Além disso, a lógica do trabalho e as teorias pseudocientíficas da época, que frequentemente defendiam a inferioridade física, biológica e intelectual da mulher, reforçavam a restrição quanto ao seu papel social: seu espaço era a casa, seu trabalho era a família, sua razão de ser eram o marido e a maternidade. Não havia motivos para sair de casa. A saída à rua, no entanto, deixa Mariana nervosa, ao invés de satisfeita com a vingança. Uma inquietação crescente parece lhe sugerir que sua atitude é pecaminosa, tensão que aumenta quando, ao acompanhar Sofia ao dentista, encontra um antigo namorado. A jovem começa a sentir-se oprimida pela culpa, pela sensação de clandestinidade: não era certo sair, não era certo conversar com outros homens, reencontrar o passado, seu tempo de solteira. A agitação de Mariana vai aumentando e a moça se arrepende de ter discordado do marido, começa a achar que talvez Conrado tivesse razão. Sente uma repentina saudade de casa, do lar que havia abandonado há algumas poucas horas.

\footnotetext{
Esta diversão não o foi para Mariana, cujo espírito plácido e uniforme, ficou atarantado no meio de tanta e tão inesperada agitação. Ela chegou a levantarse para sair; mas sentou-se outra vez. Já agora estava disposta a ir ao fim, arrependida e resoluta a chorar só consigo as suas mágoas conjugais. A dúvida começou mesmo a entrar nela. Tinha razão no pedido ao marido; mas era caso de doer-se tanto? Era razoável o espalhafato? Certamente que as ironias dele foram cruéis; mas, em suma, era a primeira vez que lhe batera o pé, e, naturalmente, a novidade irritou-o (p. 319).
}

O discurso indireto livre revela o que ia pela mente de Mariana: seu despeito e sua revolta em ser ridicularizada pelo marido, sem muita resistência, se transformaram em compreensão. Passa acreditar que agira despropositadamente e que ao "bater o pé" 
com o marido, naturalmente o irritara. O advérbio, que pode ser lido como uma afirmação ou a reiteração dela, também deve ser entendido como revelador da ideia de que para Mariana, assim como para a sociedade que a produziu e educou, era natural que um homem, quando confrontado por uma mulher, se irritasse. A jovem sente-se no compromisso de entender aquilo que a norma social dita. Assim, depois de uma breve passagem pela Câmara, onde Mariana se sentiu ainda mais deslocada, - "Que tenho eu com a Câmara? Que me importam discursos que não entendo?” (p. 318) - a jovem finalmente volta ao lar.

Em casa, "restituída a si mesma" (p. 319), Mariana está em seu habitat. Ordenou ao jardineiro que colocasse um vaso de volta em seu lugar. Ela não gostava de mudanças ou revoluções, as coisas tinham seu lugar; as pessoas tinham seus papéis: "a monotonia trazia-lhe um grande bem, e nunca lhe pareceu tão deliciosa" (p. 319). Quando Conrado retornava à casa, trazia na cabeça um outro chapéu, o que surpreendeu a esposa, que correu aos seus braços e lhe pediu que mantivesse o antigo e que botasse $o$ novo fora. Não só a mudança de chapéu, como a atitude do marido que acata as exigências da mulher, representavam "a nota desigual no meio da harmoniosa sonata da vida" (p. 320).

Infelizmente "a rebelião de Eva" (p. 315) esboçada por Mariana não chega a cumprir-se. Ao final ela faz questão de restituir o poder ao marido e se reorganiza no sentido de manter e defender o status quo. Se o projeto de emancipação encarnado por Sofia falhou na figura de Mariana, onde então se veria o feminismo de Machado de Assis mencionado no início dessa análise?

John Gledson faz uma incursão pelas figuras femininas do conto machadiano para mostrar que mesmo quando elas se conformam com o espaço restrito da opressão social e masculina cumprem o importante papel de revelar, ou ainda denunciar aos leitores a pobreza da existência feminina dentro da vida burguesa. Sejam elas frívolas como Sofia, ou passivas e dóceis como Mariana, todas são igualmente resultado de um sistema patriarcal que não as educa, que as esconde dentro de casa e que lhes concede apenas interesses superficiais: a moda, a leitura de romances tolos, a organização doméstica, a costura, etc. Em um conto da mesma época, "Uma senhora", de 1883, citado por Gledson (2006, p. 106), o narrador dispara, ao comentar a superficialidade do caráter de sua personagem: "como quer [o leitor] que vivam as mulheres do nosso tempo"? Essa pergunta poderia muito bem esclarecer o desfecho de "Capítulo dos chapéus". Poderia Mariana agir de outra forma? Parece, no entanto, que a compreensão inicial de que seu marido a humilhava e a sua ida à rua do Ouvidor se deram ao som da "Marselhesa do matrimônio".

\section{A diplomacia do casamento}

O conto "O diplomático", publicado pela primeira vez em 1884, na Gazeta de notícias, se desenvolve no seio da burguesia brasileira do século XIX, assim como a maior parte da narrativa machadiana. A trama tem lugar em uma reunião social, um jantar na noite de São João, na casa do escrivão João Viegas. A personagem-título é Rangel, um solteirão de 41 anos que recebeu dos conhecidos o apelido de "diplomático". Através da movimentação e caracterização da personagem ao longo do conto, percebe-se que a alcunha se deve a sua habilidade e esforço em se relacionar: é ele quem lê a sorte dos convidados e faz o brinde antes da ceia. Sua vida pessoal 
medíocre, sem família e posição social de destaque, é mascarada pela convivência em sociedade: é presença certa em reuniões, jantares e bailes, ainda que ocupe nesses espaços uma posição tão subalterna quanto a que ocupa na estrutura social.

A grande frequência de Rangel nesses eventos esconde, na verdade, um objetivo secreto: a esperança de um bom casamento. Há muito tempo ele sonhava com um matrimônio que pudesse lhe alçar a uma posição social superior e, graças ao "demônio das grandezas" (ASSIS, 2008, p. 420), Rangel chegara aos 41 anos solteiro. Além disso, sua presença na recepção de João Viegas tinha ainda um interesse específico: Joaninha, filha de 19 anos do dono da casa. A expectativa matrimonial, no entanto, não é o horizonte somente desta personagem, mas também de D. Felismina, outra quarentona caricata, descrita cruelmente pelo narrador como uma mulher "sem prendas, nem rendas, que vivia espiando um marido por baixo das pálpebras devotas" (p. 419).

É importante observar, entretanto, que ainda que a movimentação das personagens se oriente pela busca de uma esposa ou marido o que está em jogo aqui é a inserção social que o casamento, enquanto instituição burguesa, pode assegurar. Como nota Alfredo Bosi sobre os contos machadianos, "a maior angústia, oculta ou patente, de certas personagens é determinada pelo horizonte do status", frequentemente buscado ou alcançado através "de um matrimônio com um parceiro mais abonado" (1982, p. 437). Apesar de Rangel ser um sonhador, que idealiza uma existência gloriosa e que joga o jogo do amor de sua época, tentando estabelecer um diálogo com Joaninha através de uma carta na qual declararia seus sentimentos, o que está por trás dessa perspectiva é uma dimensão utilitária do casamento. A tentativa de aproximação traçada por Rangel obedece completamente ao rito sentimental/casamenteiro burguês: a frequência na casa, as boas relações entre os parentes e amigos, a busca por se destacar entre os convivas, a manifestação do interesse através de uma carta: "A casca é idílica, o cerne é realistaburguês" (BOSI, 1982, p. 439).

O relacionamento amoroso aqui rompe completamente com a idealização romântica, pois há pouco espaço para a espontaneidade dos sentimentos, para as surpresas e rebeldias de um coração apaixonado. A busca de Rangel é pelo reconhecimento social e a respeitabilidade que um casamento com uma moça de estrato social superior lhe traria. O matrimônio não é, assim, a formalização de um sentimento, mas sim uma instituição, uma etapa indispensável de uma trajetória social respeitável. A sociedade oitocentista passa a ver no amor "a possibilidade de ser domesticado e reorientado para fins sociais", ele torna-se "filho da biografia burguesa" (COSTA, 1983, p. 65).

Costa (1983) aponta ainda que a aristocratização da sociedade brasileira, que se dá a partir do período joanino, intensifica a vida social burguesa, o que ressignifica a importância do casamento enquanto instituição inseparável do modus vivendi das elites brasileiras. O autor ressalta, inclusive, o papel dos eventos públicos no rito casamenteiro, como o que serve de cenário a "O diplomático": "A recepção converteuse em lugar de exibição das qualidades dos filhos e de contendas entre famílias que tentavam incorporar a seus patrimônios a fortuna e os títulos do parceiro visado" ( $p$. 108).

A domesticação do amor, transformado agora em convergência de interesses entre um homem, uma mulher e suas famílias, não deixa espaço para as grandes ações impensadas, para as emoções arrebatadoras, que outrora recheavam as páginas dos romances, retratando sentimentos fatais. Rangel assiste, no mesmo jantar em que pretendia entregar a carta a Joaninha, a um rapaz novo no convívio da casa seduzir a 
todos os presentes, a moça, a seus pais e aos demais convivas. Queirós, apresentado naquele mesmo dia ao dono da casa, é jovem, bonito, elegante e muito desenvolto: sua presença na recepção causa o impacto necessário para o sucesso social - "Era o cetro que lhe caía das mãos" (ASSIS, 2008, p. 421).

Ao perceber o grande espaço que Queirós rapidamente conquista na casa, Rangel vê suas expectativas em relação a Joaninha seriamente ameaçadas. Ainda assim, ele reflete e elenca as suas vantagens em relação ao novato na casa e faz suposições sobre Queirós, para todos então um desconhecido. Nesse ponto, o pensamento de Rangel deixa claros quais são os critérios indispensáveis para a realização de um casamento com uma moça de família respeitável - não se trata de virtudes pessoais, mas sim de ter boas relações e, principalmente, condições socioeconômicas favoráveis.

Rangel passou da cólera ao desânimo, e, acabada a ceia, pensou em retirar-se. Mas a esperança, esse demônio de olhos verdes, pediu-lhe que ficasse, e ficou. Quem sabe? Era tudo passageiro, coisas de uma noite, namoro de São João; afinal, ele era amigo da casa, e tinha a estima da família; bastava que pedisse a moça para obtê-la. E depois esse Queirós podia não ter meios de casar. Que emprego teria na Santa Casa? Talvez alguma coisa reles... Nisto, olhou obliquamente para a roupa de Queirós, enfiou-se-lhe pelas costuras, escrutou o bordadinho da camisa, apalpou os joelhos das calças, a ver-lhe o uso, e os sapatos e concluiu que era um rapaz caprichoso, mas provavelmente gastava tudo consigo, e casar era negócio sério. Podia ser também que tivesse mãe viúva, irmãs solteiras... Rangel era só (p. 423).

O amor educado para o casamento, diferentemente do amor romântico, é comedido, obediente às regras e convenções sociais, age dentro daquilo que é de bom tom. Cabe aqui apontar o exemplo que Brás Cubas, talvez o maior herói burguês machadiano, também inclinado para o casamento e a respeitabilidade que ele proporciona, mas que, diante dos obstáculos que a vida lhe apresentou para a sua concretização, estagnou. Assim como Rangel, Brás não lutou pela formalização de seus relacionamentos, desistiu passivamente diante das dificuldades. À exceção de sua relação com Virgília e com Marcela, amores proibidos, onde a possibilidade de casamento era inexistente, os outros breves envolvimentos afetivos que surgem na trajetória de Brás, por razões diferentes, não atingem o status de compromisso que poderia se tornar um matrimônio. O desejo pelo casamento é manifestado por Brás algumas vezes, mas sua movimentação na narrativa para sua realização é quase nula: "o amor nas Memórias é frouxo, evitando fazer frente aos seus adversários" (SCHWARZ, 2000, p. 134).

Frouxa também se mostra a afeição de Rangel por Joaninha: em todo o tempo em que foi assíduo na casa e amigo da família, ele nunca foi capaz de manifestar-lhe suas intenções em relação à moça. Ele não chega nem mesmo a ser rejeitado, já que seu interesse nunca foi conhecido. A atitude passiva em relação às possíveis futuras esposas, tanto no caso de Brás Cubas quanto no de Rangel, revela uma falta de força sentimental, uma afeição educada para os salões das recepções burguesas. A apatia sentimental de Rangel é tanta que ele chega a ser padrinho de casamento de Joaninha e Queirós, que se realiza seis meses depois da fatídica noite de São João retratada no conto. Ainda uma vez, o diplomático é presença garantida nos mais importantes eventos sociais.

\section{0 amor dos pobres em "Noite de almirante"}


"Noite de almirante", também publicado pela primeira vez em 1884 na Gazeta de notícias, nos apresenta uma situação nova em relação aos outros contos aqui analisados: a narrativa traz personagens provenientes das classes populares. Deolindo Venta-Grande era um marujo que abandonara há alguns meses sua paixão recente, Genoveva, uma "caboclinha de vinte anos, esperta" (ASSIS, 2008, p. 349), para uma viagem de instrução. A separação dos dois jovens se deu em meio a muitas lágrimas e juras de amor e fidelidade. O conto começa quando Deolindo está de volta à terra e vai ansiosamente ao encontro de sua amada.

Ao chegar à pobre residência onde a jovem vivia com uma tia, o rapaz é surpreendido por notícias que lhe acertam como uma bofetada: Genoveva não vive mais naquela casa, apaixonou-se pelo mascate José Diogo e, apesar dos conselhos da tia que julgava a decisão muito precipitada, foi viver em companhia de seu novo amor. Deolindo, transtornado, pede informações sobre onde mora o casal e segue para lá. Ao chegar ao destino, foi recebido por Genoveva com uma naturalidade desconcertante, como se se tratasse de uma visita qualquer. " - Que é isso? Exclamou espantada. Quando chegou? Entre, seu Deolindo. E, levantando-se, abriu a rótula e fê-lo entrar" (p. 350).

Os antigos namorados começaram a conversar e inevitavelmente falaram sobre a radical mudança nos sentimentos de Genoveva. Deolindo lhe cobra a palavra dada, ela havia jurado esperá-lo. A jovem não tinha uma explicação muito satisfatória para dar a respeito de tal reviravolta. Pôde apenas dizer que a jura, na ocasião em que havia sido feita, era verdadeira, assim como a afeição que a animara, "Mas o coração mudou... Mudou..." (p. 350). Não havia outra explicação possível para o fato de que José Diogo aparecera e ela passou a gostar dele. Não havia outra causa a não ser a espontaneidade e imprevisibilidade dos sentimentos. O marujo, no entanto, não se satisfaz com o que lhe disse a moça, pois ele havia cumprido o que prometera e agora estava de volta, como haviam combinado.

Genoveva, entretanto, trata do caso com a mesma naturalidade com que suas afeições repentinamente mudaram. No passado o havia amado e por isso jurara, era tudo verdade. Agora, no entanto, as coisas haviam mudado e nada se poderia fazer sobre isso. Para ela não havia nenhuma dor ou tragédia no fato, havia apenas a necessidade de se conformar a essa nova realidade: "Genoveva não se defendia de um erro ou de um perjúrio; não se defendia de nada; faltava-lhe o padrão moral das ações" (p. 351). O narrador sugere que ainda que a moça afirmasse que seu juramento, quando feito, tinha sido verdadeiro, sua compreensão da importância desse compromisso era bem diferente da de Deolindo e das pessoas em geral. Ela desconhecia a força que tinha uma promessa como a que fizera. Compreende-se, assim, a sua tranquilidade em receber o marujo, ela não se sentia culpada de nada: "poucas lhe dariam uma expressão tão cândida, não de propósito, mas involuntariamente. Vede que estamos aqui muito próximos da natureza" (p. 351).

Apaixonar-se por Deolindo, esquecê-lo e a seguir apaixonar-se por outro homem tinham sido processos naturais e espontâneos no espírito de Genoveva, sendo assim, cumpria entendê-los como tal e assim a moça o fazia. O ex-namorado ainda lhe entregou uns brincos que lhe trouxera da viagem, e a jovem os aceitou, muito satisfeita com o presente. $\mathrm{O}$ rompimento que estão vivendo e o sofrimento do rapaz não a impedem de sentir-se merecedora do presente. Está claro que para o marujo ferido esse entendimento da situação não era possível. Ele ameaça então matar o seu rival, que não 
está em casa. "Genoveva olhou para ele com desprezo, sorriu de leve e deu um muxoxo; e, como ele lhe falasse de ingratidão e perjúrio, não pôde disfarçar o pasmo" (p. 351). A moça faz pouco caso da reação eminentemente violenta de Deolindo. Sua surpresa diante das acusações que lhe são feitas mostra que para ela, assim como as ameaças do marujo, as juras de amor não devem ser levadas tão a sério.

Tendo se esgotado as esperanças de Deolindo, assim como a possibilidade de compreensão mútua sobre a situação, com a chegada da noite e de uma vizinha que os interrompe, só resta ao rapaz ir embora. Antes de partir, ele é capaz ainda de mais uma demonstração extrema de amor ferido e diz a antiga namorada que vai se matar.

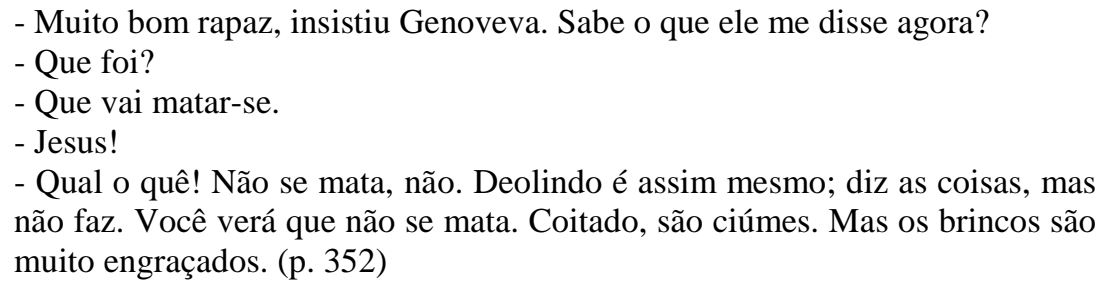

Genoveva, logo após a ameaça de suicídio do seu antigo amor, convida a amiga a coser. A jovem desfaz da ameaça de Deolindo pautando a conduta do rapaz pela sua. Ela jurou e não cumpriu, ele ameaça, mas não faz e é assim que as coisas são. Deolindo, de fato, não se mata e também não tem coragem de contar aos outros marujos, que sabiam de seu romance com a moça e de sua expectativa quanto a esse reencontro, que foi trocado por outro homem: "Parece que teve vergonha da realidade e preferiu mentir" (p. 352).

O narrador atribui o entendimento pragmático de Genoveva das questões sentimentais à sua proximidade com a natureza, "que não conheceria pecado, nem culpa, nem remorso, apenas necessidades" (BOSI, 1982, p. 452) e à sua incapacidade de agir de acordo com os padrões morais sociais. Parece que a moça tem um caráter simples e não é capaz de compreender a complexidade da situação que vive. É possível, entretanto, perceber que na visão de mundo de Genoveva há um dado social, uma relevância ideológica.

Se é lícito comparar "Noite de almirante" com os contos já analisados, percebese que a noção de comprometimento amoroso que aqui aparece é totalmente diversa. Ao contrário de Mariana, de "Capítulo dos chapéus", Genoveva é senhora de seu destino, e em suas mãos está sua relação com Deolindo. As amarras sociais e o fato de ser a mulher não a impedem de romper com as juras feitas ao marujo, nem de rapidamente ligar-se a outro homem. O mesmo se pode dizer em relação a "O diplomático", pois aqui o relacionamento amoroso não é um negócio, um acordo de interesses firmado entre noivo e a família da noiva. A "caboclinha" age espontaneamente, segue os seus desejos, que podem inclusive ser passageiros, e sente-se livre para romper com a palavra dada se sua afeição mudar.

Como visto na seção anterior, para a burguesia brasileira oitocentista o relacionamento amoroso respeitável é apenas uma etapa rumo ao casamento, que se realiza como um acordo vantajoso para as partes. O matrimônio traz prestígio social para os cônjuges, que seguem o protocolo da família burguesa, e é um negócio que permite o aumento do patrimônio e a elevação na estrutura social através da ligação a uma família importante. Nas classes baixas, entretanto, as relações amorosas não obedecem à mesma lógica burguesa: não há preocupação com as aparências, já que o convívio social não é aquele das altas rodas, dos bailes, das recepções e dos jantares 
com figuras importantes e, por isso, não segue o mesmo código de conduta. Tampouco a relação amorosa se constitui como negociata - não há patrimônio em jogo e, assim, as ligações se dão simplesmente pela imprevisibilidade do desejo e por isso podem, de um momento para o outro, mudar. A atitude de Genoveva mostra que entre os pobres, na medida em que não há nada a se perder - dinheiro, prestígio social, aparências - há uma maior liberdade, ou, para o narrador, pode-se agir naturalmente. Nesse estrato social a moral burguesa não faz sentido e, por isso, ela passa por um relaxamento que permite aos que não usam black-tie estarem mais próximos da natureza.

\section{Considerações finais}

John Gledson aponta que os contos machadianos, de sua fase dita "madura", "constroem uma espécie de história nacional bastante cética e original" (2006, p. 48). Machado de Assis explora essa propriedade narrativa minuciosa e sutilmente, pois sua lente não está posicionada para os grandes eventos sócio-históricos do Brasil do século XIX, mas sim para o cotidiano da vida privada de homens e mulheres comuns. Interessa-lhe retratar o ser e agir da sociedade brasileira oitocentista para compreender assim o processo histórico de seu tempo.

Dessa forma, na obra do grande escritor carioca, as relações entre homens e mulheres assumem uma dimensão mais profunda e complexa do que o amor trabalhado pelos românticos. Os laços entre as personagens revelam os diferentes papéis reservados não só a homens e mulheres, mas também aos estratos sociais nos quais se inserem. $\mathrm{O}$ relacionamento afetivo e, mais ainda, o casamento têm significados e valores diferentes que repercutem as contradições ideológicas da sociedade brasileira da época.

Os três contos aqui analisados permitem que o cotidiano das personagens e seu modo de se relacionar iluminem o caráter da sociedade brasileira do século XIX, a mesma que escravizou e aboliu a escravidão, que se transformou em República, que se dividiu e se fixou em classes sociais cruelmente bem definidas. Essas narrativas permitem refletir sobre como nos relacionamos historicamente e sobre como o processo histórico influencia e conduz nossa vida privada, inserindo-nos assim ativamente, ainda que inconscientemente, como participantes dele.

\section{REFERÊNCIAS}

ASSIS, Joaquim Maria Machado de. Contos reunidos. Porto Alegre: Pradense, 2008.

BOSI, Alfredo. A máscara e a fenda. In: _ Machado de Assis: antologia e estudos. São Paulo: Ática, 1982. p. 437- 457.

CHALHOUB, Sidney. Machado de Assis historiador. São Paulo: Companhia das Letras, 2003.

COSTA, Jurandir Freire. Ordem médica e norma familiar. Rio de Janeiro: Edições Graal, 1983. 
GLEDSON, John. Por um novo Machado de Assis: ensaios. São Paulo: Companhia das Letras, 2006.

SCHWARZ, Roberto. O sentido histórico da crueldade em Machado de Assis. In: _ As ideias fora do lugar: ensaios selecionados. São Paulo: Penguin Classics Companhia das Letras 2014. p.65-80.

Um mestre na periferia do capitalismo: Machado de Assis. São Paulo: Duas cidades; Ed.34, 2000. 